\title{
An estimate of the lead isotopic compositions of upper mantle and upper crust and implications for the source of lead in the Jinding $\mathrm{Pb}-\mathrm{Zn}$ deposit in Western Yunnan, China
}

\author{
ZHANG QIAN*, LIU JiAJUN, SHAO SHUXUN and LIU ZHIHAO \\ The Open Lab. of Ore Deposit Geochemistry, Institute of Geochemistry, Chinese Academy of Sciences, \\ Guiyang 550002, China
}

(Received April 5, 2001; Accepted March 11, 2002)

\begin{abstract}
The Jinding $\mathrm{Pb}-\mathrm{Zn}$ deposit occurs in the Tertiary red sedimentary formation of the Cenozoic continental fault depression basin at Lanping, western Yunnan. The orebodies are stratiform and stratoid in form and giant in size, with the associated $\mathrm{Sr}$ and $\mathrm{Cd}$ being of high grade. In the past thirty years the source of lead in this deposit has been a long-standing controversial problem. Some scholars considered that lead came from the upper mantle while others shed doubt on that viewpoint. However, no conclusive evidence has been obtained to support their respective viewpoints, and to find a more definite answer to the above question. We have re-examined the lead isotopic composition of the Jinding $\mathrm{Pb}-\mathrm{Zn}$ deposit. The lead isotopic ratios of the striped ore are ${ }^{206} \mathrm{~Pb} /{ }^{204} \mathrm{~Pb}=18.138-18.552,{ }^{207} \mathrm{~Pb} /{ }^{204} \mathrm{~Pb}=15.345-15.552$, and ${ }^{208} \mathrm{~Pb} /$ ${ }^{204} \mathrm{~Pb}=37.803-38.443$, and the lead isotopic ratios of the massive ore are ${ }^{206} \mathrm{~Pb} /{ }^{204} \mathrm{~Pb}=18.394-18.600$, ${ }^{207} \mathrm{~Pb} /{ }^{204} \mathrm{~Pb}=15.583-15.767$, and ${ }^{208} \mathrm{~Pb} /{ }^{204} \mathrm{~Pb}=38.266-39.046$. In terms of the lead isotopic composition of minerals and whole rock samples from basic-ultrabasic rocks and alkaline rockbodies in the region of western Yunnan, we have determined the lead isotopic composition of the upper mantle in this region at Meso- and Cenozoic times, as ${ }^{206} \mathrm{~Pb} /{ }^{204} \mathrm{~Pb}=17.850-18.350,{ }^{207} \mathrm{~Pb} /{ }^{204} \mathrm{~Pb}=15.430-15.540$, and ${ }^{208} \mathrm{~Pb} /$ ${ }^{204} \mathrm{~Pb}=37.800-38.410$. Then in the light of the lead isotopic composition of metamorphic rocks and sedimentary rocks from Precambrian to Tertiary, which are exposed in the Lanping Basin and its adjacent areas, we have determined the lead isotopic composition of the upper crust, as ${ }^{206} \mathrm{~Pb} /{ }^{204} \mathrm{~Pb}=18.420$ $19.200,{ }^{207} \mathrm{~Pb} /{ }^{204} \mathrm{~Pb}=15.500-16.010$, and ${ }^{208} \mathrm{~Pb} / 204 \mathrm{~Pb}=38.450-39.500$, and several mineral samples from granulite and eclogite xenoliths yielded the lead isotopic information of the lower crust, as ${ }^{206} \mathrm{~Pb} /{ }^{204} \mathrm{~Pb}=$ $18.135-18.187,{ }^{207} \mathrm{~Pb} /{ }^{204} \mathrm{~Pb}=15.335-15.388$ and ${ }^{208} \mathrm{~Pb} /{ }^{204} \mathrm{~Pb}=37.836-37.899$. A comparison has been made with the lead isotopic composition of the ore, and it is indicated that lead in the Jinding $\mathrm{Pb}-\mathrm{Zn}$ deposit was not derived from the upper mantle, and there are two sources of lead: one is the upper crust and the other is the lower crust.
\end{abstract}

\section{INTRODUCTION}

The Jinding deposit is the largest-scale $\mathrm{Pb}-\mathrm{Zn}$ ore deposit in China. It is characterized as being terrestrial redbed strata-bound (sedimentary metallogenesis in the terrestrial basin), young in metallogenic age (Himalayan metallogenesis) and associated with super-large $\mathrm{Sr}$ deposits. Since the early 1980's much beneficial work has been done on this deposit. In regard to the genesis of this deposit, two hypotheses have been put forward, i.e., sedimentation-reworking origin according to the stratiform ore bodies and high ore-forming temperature (from $270^{\circ} \mathrm{C}$ to $350^{\circ} \mathrm{C}$ ). Its ore-forming metal elements are considerably derived from the sedimentary rocks in the basin (Tu et al., 1984; Bai et al., 1985), and terrestrial exhalative-hydrothermal sedimentary origin as evidenced by the characteristics of the deposit similar to those of the SEDEX deposits, whose ore-forming metal

*Corresponding author (e-mail: zhqian@public.gz.cn) 
elements are considerably derived from the upper mantle and/or the basement rocks of the basin ( $\mathrm{Li}$ et al., 1993). The lower isotopic ratios in most galena samples from this deposit indicated that the lead was derived from the upper mantle (Yin et al., 1990; Luo et al., 1992; Tu et al., 2000). However, in their He-Ar isotopic tracing study, $\mathrm{Hu}$ et al. (1998) held that there is no mantle-source helium in this deposit. The isotopic compositions of $\mathrm{S}, \mathrm{O}, \mathrm{C}, \mathrm{H}$, and $\mathrm{Sr}$ provide reliable information to show that these elements were derived from the crust (Luo et al., 1992; Tu et al., 2000). No signs of magmatic activities of pyrolites on a large scale are noted within the mining district. So it has become questionable whether lead in the Jinding deposit comes from the upper mantle or not. For this reason, we have re-examined the origin of lead in the deposit. Our research thought is: (1) A direct approach to determining the source of oreforming materials in $\mathrm{Pb}-\mathrm{Zn}$ deposits is the lead isotopic composition; (2) On the basis of a better understanding of the lead isotopic composition of rocks from the upper mantle, the upper crust and the lower crust-derived xenoliths in the region of western Yunnan, a comparison will be made with the lead isotopic composition of the ore, in conjunction with its geochemical and geological characteristics, so as to constrain the origin of lead in this deposit.

\section{Geological Characteristics OF THE DEPOSIT}

\section{Stratigraphy and lithological character}

With reference to the structural relations, the strata exposed in the mining district can be divided into two parts: the in-situ system and the exotic system. The exotic system includes the Upper Triassic Waigucun Formation, the Sanhedong Formation, the Maichuqing Formation and the Middle Jurassic Huakaizuo Formation, which have been thrusted by large overthrust faults onto the Tertiary strata. Lithologically, shore- and shallow sea-facies sedimentary limestones, sandstones, siltstones and argillaceous siltstones are dominant, which are distributed mainly on both limbs of the domes. The most significant visual difference between the exotic system and the in-situ system is that the former is dominated by grayish-white rocks and the latter by red and purple red rocks. The in-situ system consists of the Lower and Upper Tertiary series and the Quaternary system, with a total thickness of 689-940 m. The Cretaceous strata are distributed mainly in the periphery of the mining district, the Upper Tertiary strata are distributed in the northwestern part of the mining district and the Quaternary deposits are distributed along the river valley (Fig. 1). The Lower Tertiary Yunlong Formation strata comprise three lithological units $(a, b, c)$. Ey ${ }^{a}$ stands for a suite of purple red argillaceous siltstones, measuring $300 \mathrm{~m}$ in thickness, at the foot wall of the ore beds. At the bottom, a 1.5-10 m thick layer of limestone breccias is developed. The sediments of $\mathrm{Ey}^{\mathrm{a}}$ bed become coarse in grain size from west to east, and belong to arid, salt-lake facies. It has a transitional relationship with the overlying strata $\left(\mathrm{Ey}^{\mathrm{b}}\right)$. In the $\mathrm{Ey}^{\mathrm{b}}$ unit there are developed limestone breccia and slip-collapse breccia in the east, giving way to breccia, purple-red sandstone and purple-red to grayish-white muddy sandstone in the west. In going from east to west, the breccias tend to become smaller and smaller in scale while the bedding tends to become more and more distinct. In most cases the Ey ${ }^{\mathrm{b}}$ strata, with a thickness of $400 \mathrm{~m}$, are in fault contact with the overlying Ey ${ }^{\mathrm{c}}$ strata. The Ey ${ }^{\mathrm{c}}$ strata are made up of quartzose sandstone and breccia-bearing quartzose sandstone. At the bottom limestone breccia, marl breccia and dolomite breccia are developed, and at the top limestone lenses are occasionally developed. Horizontal bedding is recognized at the top and oblique bedding is seen in the middle part, in fault contact with the overlying exotic system, measuring $<100 \mathrm{~m}$ in thickness.

\section{Structure and magmatic activity}

As the Jinding ore field is located in the Mesozoic Sanjiang folded zone (the name Sanjiang is referred to the Jinsha River, Lancang River and Nu River), in conjunction with the collision-compression of the Indian Plate, the fault 


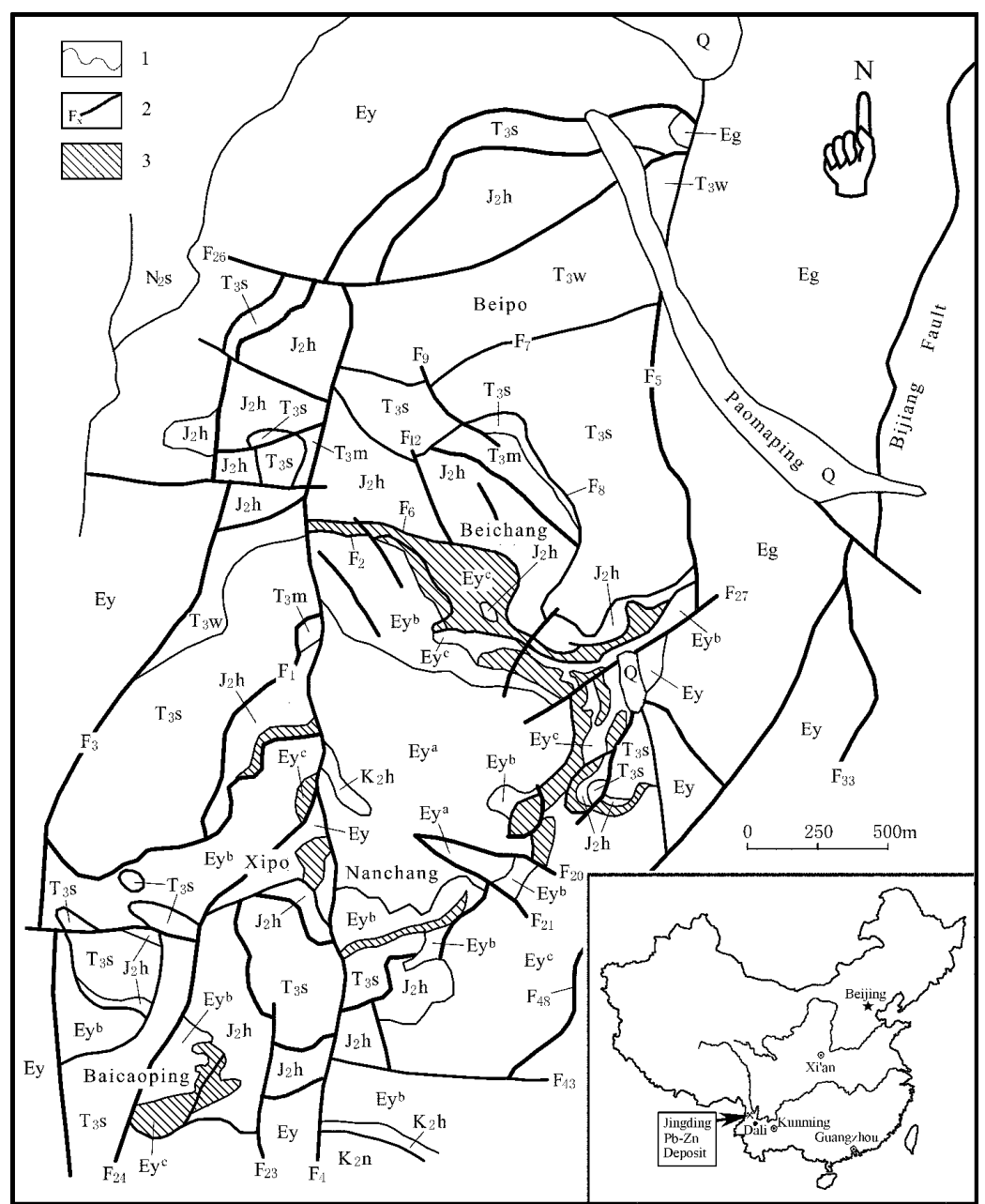

Fig. 1. Geological map of the Jinding Pb-Zn deposit. Q: Quaternary; $N_{2}$ s: Sanying Formation of Upper Pliocene, Upper Tertiary; Ey: Yunlong Formation of Paleocene, Lower Tertiary; Ey ${ }^{c}$ : the upper member of the Yunlong Formation; Ey $y^{b}$ the middle member of the Yunlong Formation; Ey $y^{a}$ the lower member of the Yunlong Formation; Upper Cretaceous: $K_{2} h$ : Hutoushi Formation; $K_{2} n$ : Nanxing Formation; $\mathrm{J}_{2} h$ : Middle Jurassic Huakaizuo Formation; Upper Triassic: $T_{3} m$ : Maichuqing Formation; $T_{3}$ s: Sanhedong Formation; $T_{3}$ w: Waigushu Formation. 1. Strata boundary; 2. Fault; 3. Orebody.

structures are well developed. The Lanping Basin is an inland fault depression basin controlled by a deep fault zone (Fig. 2). On the eastern side of the mining district the Bijiang fault zone extends from south to north with a total length of $120 \mathrm{~km}$ (Figs. 1 and 2). This fault zone is a long-term active synsedimentary fault which controls the sedimentary facies of the in-situ system strata. The $\mathrm{Pb}-\mathrm{Zn}$ mineralization, pyritization and decolourization are recognizable along this fault zone. So this fault zone may be an important oreconduit structure.

Li (1994) investigated the reverse thrust nappe structure in the Lanping Basin. In the Jinding ore field the reverse thrusting of large-scale nappe faults $\left(\mathrm{F}_{1}, \mathrm{~F}_{2}, \mathrm{~F}_{3}, \mathrm{~F}_{4}\right)$ made the Mesozoic strata overlap the Tertiary red beds (Figs. 1 and 3). The reverse thrusting event took place after the sedimentation and diagenesis of the Lower Tertiary Yunlong Formation strata dated at about 65 to 50 


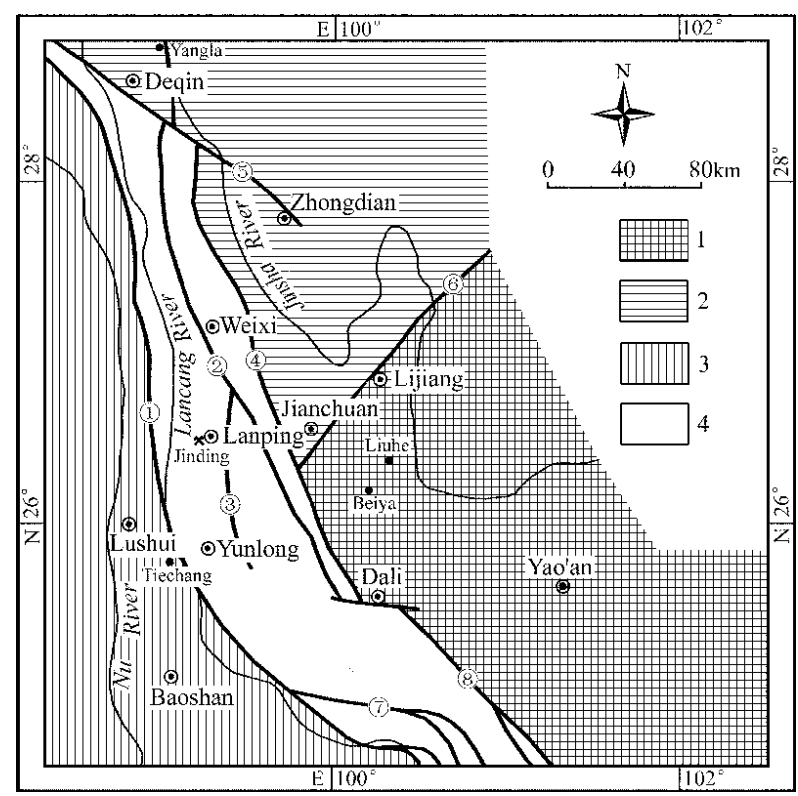

Fig. 2. The geological map of the Lanping basin. 1. Yangtze plate; 2. Zhongdian minor plate; 3. Tibet-Yunnan plate; 4. Lanping basin; (1) Lancangjiang fault; (2) Cangshan fault; (3) Bijiang fault; (4) Jinshajiang fault; (5) Deqin-Zhongdian fault; (6) Lijiang fault; (7) Wuliangshan fault; (8) Mojiang fault.

Ma in age (Li, 1994). Based on our study on the regional geology, the time at which the reverse thrusting event took place is synchronous with that of orogenic uplifting of the basin in the Early Himalayan (Alpine) movement which started approximately $40 \mathrm{Ma}$ in western Yunnan. Li et al. (2000) studied the thermal events of the Jinding deposit with the fission track method on phosphorite from the altered Tertiary ( $>40 \mathrm{Ma}$ ) and Jurassic wall rocks (sandstone) of the ore-bodies, and the results showed that a large thermal event took place from $25 \mathrm{Ma}$ to $35 \mathrm{Ma}$ in the ore field. This age probably represents a main ore-forming event.

In the mining district the Tertiary strata constitute a large-sized domal structure, in the middle part of which lies the lower member of the Yunlong Formation and in the periphery of which are the middle and upper members of the Yunlong Formation and Mesozoic strata. On the western and northern rims this dome is relatively steep and on the eastern and southern rims it is relatively gentle with respect to its attitude. The top part of the dome has been eroded, but if reverting to the original form (Fig. 3), it is apparent that the re- verse thrusting and dome structures play an important role in mineralization, and mudstone and argillaceous siltstone $\left(\mathrm{J}_{2} \mathrm{~h}\right)$ form an effective confining bed for ore-forming fluid.

In the vast range of the mining district and its periphery there is not exposed any type of magmatic rocks.

\section{Geology of the deposit}

The Jinding $\mathrm{Pb}-\mathrm{Zn}$ deposit occurs in the red sedimentary formation of the Lower Tertiary Yunlong Formation in the Lanping Cenozoic continental basin (Figs. 1 and 3). There are more than 380 orebodies, of which there are sixteen major ones, with a tonnage of $\mathrm{Pb}+\mathrm{Zn}$ exceeding $20 \mathrm{Mt}$. The associated $\mathrm{Sr}$ content reaches the grade of a large-tonnage $\mathrm{Sr}$ deposit. The associated $\mathrm{Cd}$ has a tonnage of about $0.20 \mathrm{Mt}$.

According to the position of ore-host strata, the upper and lower ore-host beds are distinguished. Ey ${ }^{\mathrm{c}}$ represents the upper ore-host bed. Stratiform and stratoid orebodies are predominating, which are controlled by the stratigraphic position and lithological character. The upper ore- 


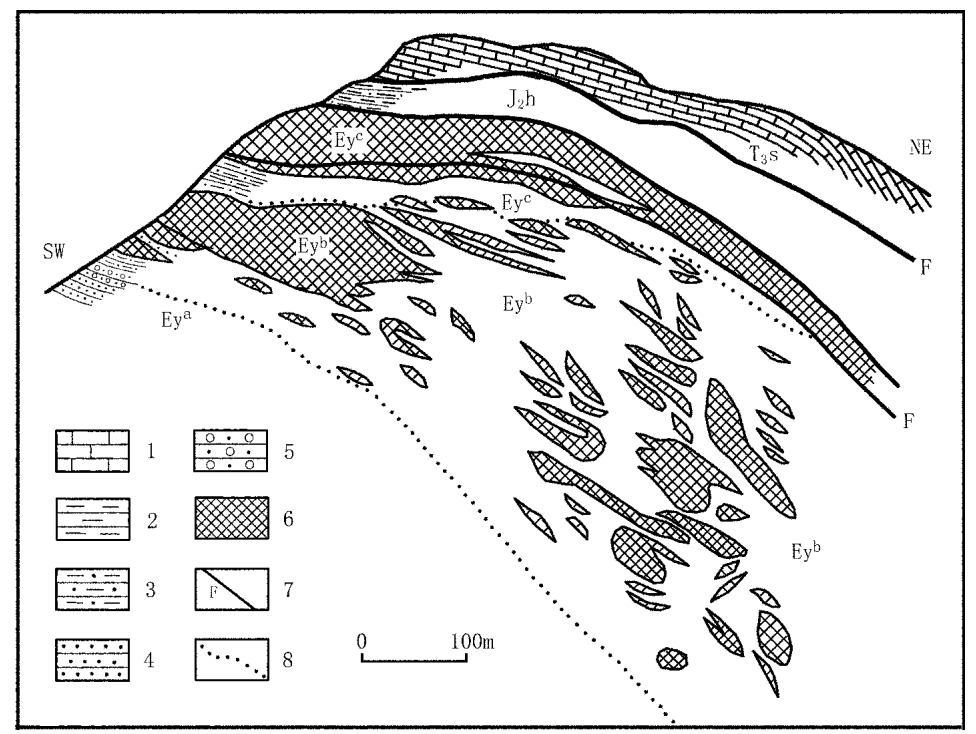

Fig. 3. The cross section of the Jinding Pb-Zn deposit. 1. Limestone; 2. Mudstone; 3. Argillaceous siltstone; 4. Sandstone; 5. Conglomerate; 6. Orebody; 7. Fault; 8. Strata boundary.

host bed is dominated by the sandstone-type ores and there is a transitional relation between the orebodies and the wall rocks. Orebody $\mathrm{I}_{1}$, the largest in the upper ore-host bed, is $1450 \mathrm{~m}$ long, 1360 $\mathrm{m}$ obliquely deep, and 10-40 m thick. The orebodies extend in the E-W direction, dipping $10^{\circ}-30^{\circ}$ northwards, and contain on the average $1.51 \% \mathrm{~Pb}, 8.32 \% \mathrm{Zn}, 13 \mathrm{ppm} \mathrm{Ag}$ and $230 \mathrm{ppm}$ Cd.

Metallic minerals in the sandstone-type ores are usually present in the form of cements of detritus (e.g., quartz) in sandstone and, therefore, the ores often exhibit cement texture and disseminated and banded structures at the edges of the orebodies. But under microscope, it is observed that the coarse-grained metallic minerals (galena and sphalerite) have replaced the fine-grained metallic minerals and the cement in the sandstone. There exist massive coarse-grained ores within the orebodies. This probably indicates that the formation of the sandstone-type ores involves two stages: early synsedimentary mineralization and late hydrothermallymetasomatic mineralization.

The lower ore-host bed is situated within the Ey ${ }^{\mathrm{b}}$ unit and contains lenticular, tubular and irregular orebodies in addition to stratiform and stratoid ones (Fig. 3). The limestone-type or the limestone breccia-type ores are developed in the lower ore-host bed. It is commonly observed that mineralization is the result of replacement of limestone breccias in the rocks. The ores commonly exhibit a wide range of textures including metasomatic-resorption, milk-drop, concentric ring and granular textures, and massive, disseminated, brecciated, banded and comprising network structures, etc. Extensive metasomatism in the lower ore-hosted bed indicates that the ores are mainly formed from hydrothermal solutions in the late mineralizing stage. The typical tubular orebody VII in the lower ore-host bed occurs in the limestone breccia overlying the Ey ${ }^{\mathrm{b}}$ strata, which is $580 \mathrm{~m}$ long, $215 \mathrm{~m}$ deep and $20 \mathrm{~m}-102$ $\mathrm{m}$ thick and contains $2.42 \% \mathrm{~Pb}, 11 \% \mathrm{Zn}$ and 130 ppm Cd. The celestite orebodies occur mainly in the limestone breccia of the Beichang ore run, some occurring as independent celestite orebodies and some as complex orebodies associated with $\mathrm{Pb}$ and $\mathrm{Zn}$.

Different ore-host beds and different types of ores obtain almost similar metallic minerals, with galena, sphalerite and pyrite being dominant. Usually the minerals are fine in grain size and it is 
commonly seen that galena and pyrite are cementing and framboidal in form at the edges of the orebodies in the western ore-field. The framboidal pyrite is sometimes found embracing granular galena. The minerals in the eastern ore-field are coarse in grain size and the massive ores are common. The gangue minerals are dominated by quartz, gypsum, barite and celestite. Wall-rock alterations are diverse in type though not so intensive, and silicification, calcitization, dolomitization and baritization are commonly seen.

The ore-forming temperature is relatively high, as is evidenced by the homogenization temperatures of the fluid inclusions in sphalerite of massive ores ranging from $270^{\circ} \mathrm{C}$ to $350^{\circ} \mathrm{C}$. From east to west, the ore-forming temperature trends to decrease from $350^{\circ} \mathrm{C}$ to $270^{\circ} \mathrm{C}$ ( Tu et al., 1984 ; Chen et al., 1996). This indicates that the oreforming fluid moves in the direction from east to west.

\section{Samples and Analytical Procedure}

\section{Sampling}

In order to reveal the isotopic composition of upper mantle lead in the region of western Yunnan, we collected samples of basic-ultrabasic rocks, alkaline rocks and deep-source inclusions from Beiya, Dali, Jinchang and Laowangzhai and picked out 13 mineral samples including plagioclase, garnet and olivine, and one serpentinized peridotite. These rock samples are considered as mantle-source magmatic rocks (Deng et al., 1998; Bian, 1998; Xu et al., 1999). Four basalt samples and nine hydrothermal sulfide (pyrite and chalcopyrite) samples in the Yangla $\mathrm{Cu}$ deposit which occurs in basalts were collected from the northern margin of the Laping Basin. Of the four basalt samples, one shows obvious signs of alteration (e.g., silicification and sericitization). According to Pan et al. $(2000,2001)$, the origin of this deposit is related to basaltic magmatism and its ore-forming materials are derived from the mantle.

The lead isotopic composition of upper-crust sedimentary rocks in the region of western Yunnan was modeled on the basis of that of the metamorphic rocks mainly including schist and gneiss from Early to Middle Proterozoic, whose primitive rocks are sedimentary rocks and were metamorphosed during the Jinning Movement (took place at $800 \mathrm{Ma}$ ) (Zhong et al., 1998), and sedimentary rocks from Cambrian to Tertiary in the Lanping Basin and its adjacent areas. Luo et al. (1992) analyzed 42 whole-rock samples from this region. Eight years later, we analyzed another 12 Mesoand Cenozoic whole-rock samples in an attempt to attest the consistency and reliability of the isotopic composition data obtained by different authors at different times.

Forty-three galena samples from the Jinding deposit were systematically analyzed for $\mathrm{Pb}$ isotopes by the Yunnan Provincial Bureau of Geology and Mineral Resources in 1980's and published by Luo et al. (1992). The conclusion that lead in the Jinding deposit stemmed from the upper mantle is based on this set of lead isotopic composition data. Additionally, eight massive coarse-grained galena samples were collected in this study from the limestone-hosted breccia-type and sandstone-type ores and four samples of galena embraced in framboid pyrite were collected from the margins of ore-bodies in the upper orehost bed. Thus a total of 51 samples were collected in this study.

\section{Analytical method}

The sample pretreatment procedure was described by Robin et al. (1999). Galena sample (200 mg) was dissolved with $\mathrm{HNO}_{3}$, and rinsed with water, followed by the loading of lead onto the $\mathrm{Re}$ filaments with a mixture of silica gel $+\mathrm{H}_{3} \mathrm{PO}_{4}$ for analysis. The whole-rock samples and feldspar, garnet and olivine samples (400 mg) were dissolved in the mixed solution of $\mathrm{HF}, \mathrm{HCl}$ and $\mathrm{HBr}$; chalcopyrite and pyrite $(400 \mathrm{mg})$ were first washed with $\mathrm{HCl}$ to remove impurities coated on the surface of the minerals, then dissolved with aqua regia while heating, and finally converted to a $\mathrm{HBr}$ chromatographic solution. The $\mathrm{Pb}$ in the solution was eluted using an ion exchange resin with $\mathrm{HBr}$ - 
HCl.

Of 51 samples, 28 samples were used for lead isotopic analysis on a VG-354 mass spectrometer at the Isotope Laboratory of the Institute of Geology, Chinese Academy of Sciences and 21 samples on a MAT-261 mass spectrometer at the Isotope Analysis Center of the Yichang Institute of Geology and Mineral Resources, Chinese Academy of Geological Sciences, respectively. Of the samples, $20 \%$ was repeatedly analyzed. The fractionation factor $(0.1 \%$ per amu $)$ is worked out in terms of the results of lead isotopic analyses of NBS-981 as the international standard samples so as to make correlations for the lead isotopic ratios of the samples. The measurements of the common-lead standard NBS-981 gave average values of ${ }^{206} \mathrm{~Pb} /{ }^{204} \mathrm{~Pb}=16.923 \pm 3,{ }^{207} \mathrm{~Pb} /{ }^{204} \mathrm{~Pb}=$ $15.467 \pm 3,{ }^{208} \mathrm{~Pb} /{ }^{204} \mathrm{~Pb}=36.733 \pm 6$ for MAT354 and ${ }^{206} \mathrm{~Pb} /{ }^{204} \mathrm{~Pb}=16.924 \pm 3,{ }^{207} \mathrm{~Pb} /{ }^{204} \mathrm{~Pb}=$ $15.468 \pm 3,{ }^{208} \mathrm{~Pb} /{ }^{204} \mathrm{~Pb}=36.732 \pm 6$ for MAT261 with uncertainties $<0.1 \%$ at the $95 \%$ confidence level. The bulk lead blanks of the whole procedure are $<1 \mathrm{ng}$ and the analytical results for all the samples are corrected by this. The duplicate analysis indicates similar reproducibilities in all cases. The bulk error is $<0.1 \%$ for all samples.

In order to understand the influence of $U$ and Th in the whole-rock, feldspar, garnet and olivine samples on the lead isotopic composition, the ICPMS techniques were employed to determine the contents of $\mathrm{U}, \mathrm{Th}$ and $\mathrm{Pb}$ in these samples, with the detection limit being $1 \mathrm{ppm}$. The analytical results show that the four basalt samples contain 10-20 ppm Pb and 1-2 ppm U, Th; feldspar, garnet and olivine contain 18-28 ppm $\mathrm{Pb}$ and $\mathrm{U}$, Th $<1 \mathrm{ppm}$; the 12 stratum samples contain 10-23 ppm $\mathrm{Pb}, 0.2-0.4$ ppm U and 4-7 ppm Th. The oreforming age of this deposit is 25 to $35 \mathrm{Ma}(\mathrm{Li}$, 2000). The calculated radiogenic $\mathrm{Pb}$ composition from decay of radioactive elements after ore deposition is within the scope of the analytical errors, and their calculated radiogenic ${ }^{206} \mathrm{~Pb} /{ }^{204} \mathrm{~Pb}$ values are $<0.006,{ }^{207} \mathrm{~Pb} /{ }^{204} \mathrm{~Pb}$ values are $<0.004$ and ${ }^{207} \mathrm{~Pb} /{ }^{204} \mathrm{~Pb}$ values $<0.008$, implying that all the analytical results can be directly adopted in the discussion.

\section{Pb ISOTOPIC COMPOSITION OF THE UPPER MANTLE IN WeSTERN YUNNAN}

Lu et al. (1993) and Deng et al. (1998) examined the lead isotopic composition of basicultrabasic rocks (gabbro, peridotite, anorthosite, etc.) and alkaline rocks (mainly quartz-syenite, quartz-orthophyre, aegirine syenite porphyry, cascadite, syenite-porphyry, etc.) in the region of western Yunnan. From their detailed research on lithology, trace-element and isotopic geochemistry, Tu (1989), Deng et al. (1998), Bian (1998) and Xu et al. (1999) considered that these rocks are derived from the mantle of the region. Liu et al. (1999) projected the lead isotopic compositions of alkaline rocks (whole rock) $\left({ }^{206} \mathrm{~Pb} /\right.$ ${ }^{204} \mathrm{~Pb}=17.498-18.847,{ }^{207} \mathrm{~Pb} /{ }^{204} \mathrm{~Pb}=15.410$ $\left.15.728,{ }^{208} \mathrm{~Pb} /{ }^{204} \mathrm{~Pb}=38.415-39.191\right)$ into the plumbotectonics model of Zartman and Doe (1981), and found that some samples are located near the zero termination of the mantle lead evolution line. It follows that the alkali-rich porphyries are magmatic rocks probably of mantle derivation. Although the lead isotopic composition of the whole alkaline rocks bears some information about the mantle, the lead isotopic ratios vary over an apparent large scope and the largest value is noticed for radiogenic lead. There are two main aspects pertaining to lead isotopes in the rocks. One is radiogenic lead which generated from radioactive elements such as $\mathrm{U}$ and $\mathrm{Th}$ after the formation of the rocks, and the other is the contamination of crustal materials. That is to say, the whole-rock lead isotopic composition of these rock-bodies could by no means represent the lead isotopic composition of the upper mantle in the region studied.

The lead isotopic compositions of thirteen minerals including plagioclase, garnet and olivine and one serpentinized peridotite are shown in Table 1 . The lead isotopic ratios are: ${ }^{206} \mathrm{~Pb} /{ }^{204} \mathrm{~Pb}=$ $17.877-18.460,{ }^{207} \mathrm{~Pb} /{ }^{204} \mathrm{~Pb}=15.465-15.543$, and ${ }^{208} \mathrm{~Pb} /{ }^{204} \mathrm{~Pb}=37.797-38.520$, respectively. Lead isotopic ratios in the whole-rock samples of basalt from the Yangla $\mathrm{Cu}$ deposit on the northern margin of the basin are: ${ }^{206} \mathrm{~Pb} /{ }^{204} \mathrm{~Pb}=18.056-$ 


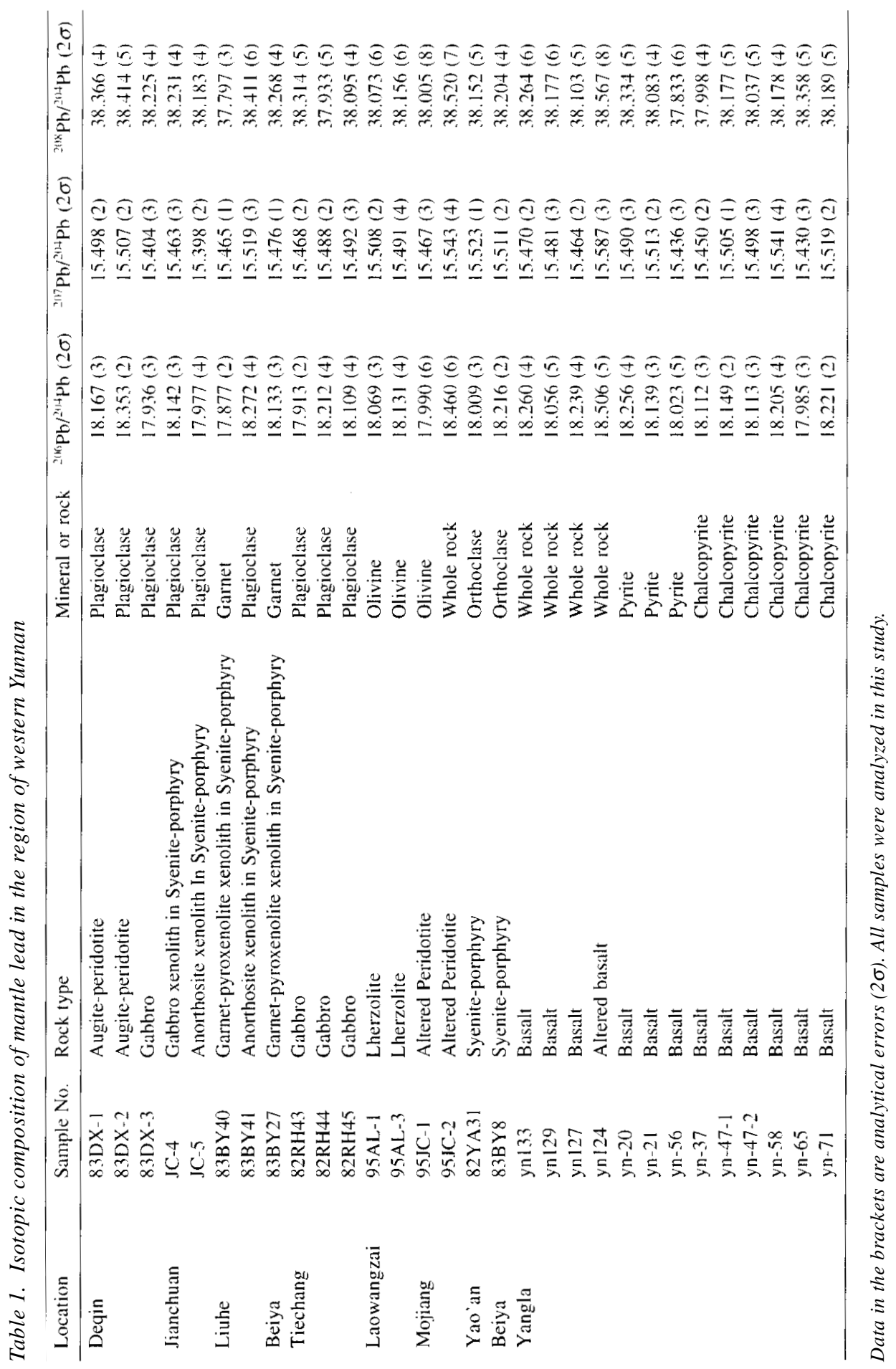



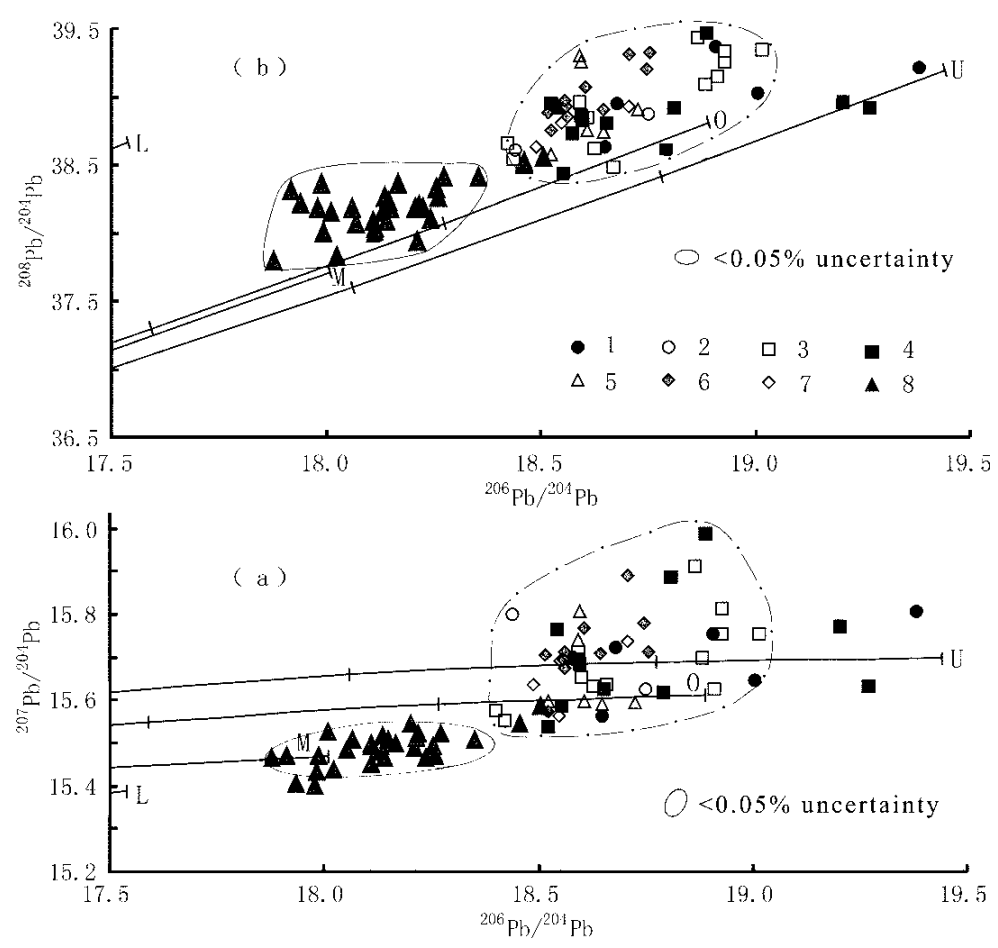

Fig. 4. Lead isotopic compositions of the upper mantle in western Yunnan and the upper crust in the Lanping Basin. Zartman's lead evolution model: M. upper mantle lead; O. orogenic belt lead; U. upper crustal lead; L. lower crustal lead. 1. Precambrian metamorphic rock; 2. Cambrian; 3. Permian; 4. Triassic; 5. Jurassic; 6. Cretaceous; 7. Tertiary; 8. Upper mantle lead in western Yunnan.

$18.506,{ }^{207} \mathrm{~Pb} /{ }^{204} \mathrm{~Pb}=15.470-15.587$, and ${ }^{208} \mathrm{~Pb} /$ ${ }^{204} \mathrm{~Pb}=38.103-38.567$, respectively. Lead isotopic ratios of sulfide samples from the ores of the Yangla copper deposit are: ${ }^{206} \mathrm{~Pb} /{ }^{204} \mathrm{~Pb}=17.985-$ $18.256,{ }^{207} \mathrm{~Pb} /{ }^{204} \mathrm{~Pb}=15.434-15.519$, and ${ }^{208} \mathrm{~Pb} /$ ${ }^{204} \mathrm{~Pb}=37.833-38.358$, respectively. The lead isotopic composition of these samples mentioned above is significantly different from that of the whole rocks. The lead isotopic values are more homogeneous and are lower than those of the whole rocks. As observed in the plumbotectonics diagram of Zartman and Doe (1981) (Fig. 4), the data points of all samples fall on the mantle lead evolution line or are distributed in the extending direction along this evolution line. Along the long axis the variation range so defined is well consistent with the mantle lead evolution line. According to Pan et al. (2001), lead in the Yangla $\mathrm{Cu}$ deposit is believed to have stemmed from the upper mantle, with almost no contamination by crustal materials. Our data for basaltic rocks at Yangla are consistant with this view and suggest that the data points falling within the areas defined by solid lines, as shown in Fig. 4, can represent the lead isotopic composition of the upper mantle since Late Paleozoic in the region of western Yunnan.

\section{THE LEAd ISOTOPIC COMPOSITION OF UPPER Crustal Rocks in the LANPING Basin}

The upper crustal rocks exposed in the Lanping Basin and its periphery include the Precambrian Chongshan Group and Cangshan Group metamorphic rocks and the Cambrian to Tertiary sedimentary rocks. The lead isotopic compositions of 54 whole-rock samples are presented in Table 2. The results show that although the strata are different in geological age (from $1800 \mathrm{Ma}$ to $60 \mathrm{Ma}$ ) and lithological character (migmatite, gneiss, schist, 
Table 2. The Pb isotopic composition of the strata at different levels in the Lanping Basin

\begin{tabular}{|c|c|c|c|c|c|c|c|}
\hline Stratigraphic & Location & $\begin{array}{c}\text { Sequence } \\
\text { No. }\end{array}$ & Sample No. & Rock type & $\begin{array}{c}{ }^{206} \mathrm{Ph} /{ }^{204} \mathrm{~Pb} \\
(2 \sigma)\end{array}$ & $\begin{array}{c}{ }^{2077} \mathrm{~Pb} / /^{2(t)+} \mathrm{Pb} \\
(2 \sigma)\end{array}$ & $\begin{array}{c}{ }^{2}(1) \mathrm{Pb} /{ }^{2(1)} \mathrm{Pb} \\
(2 \sigma)\end{array}$ \\
\hline \multirow[t]{5}{*}{ Precambrian } & Cangshan & 1 & DXQ3 & Schist & 18.679 & 15.722 & 38.955 \\
\hline & & 2 & $\mathrm{DXQ}_{4}$ & Migmatite & 18.906 & 15.754 & 39.373 \\
\hline & & 3 & DXQ5 & Migmatite & 19.004 & 15.646 & 39.031 \\
\hline & Chongshan & 4 & DXQ33 & Migmatite & 19.380 & 15.808 & 39.209 \\
\hline & & 5 & DXQ34 & Granite & 18.650 & 15.562 & 38.636 \\
\hline \multirow[t]{2}{*}{ Cambrian } & Deqing & 6 & NG4 & Schist & 18.750 & 15.417 & 37.878 \\
\hline & Sanjiacun & 7 & D7Q 53 & Dolomite & 18.140 & 15.801 & 38.613 \\
\hline \multirow[t]{12}{*}{ Permian } & Yangla, Deqing & 8 & $y n-26$ & Silicalie & $18.397(6)$ & $15.575(4)$ & $38.602(7)$ \\
\hline & & 9 & $y n-120$ & Slate & $19.014(5)$ & $15.754(3)$ & $39.348(7)$ \\
\hline & & 10 & yn-14l & Slate & $18.911(5)$ & $15.625(3)$ & $39.149(6)$ \\
\hline & & 11 & $y n-122$ & Marble & $18.423(4)$ & $15.554(2)$ & $38.555(6)$ \\
\hline & & 12 & $y n-117$ & Andesite & $18.882(6)$ & $15.700(3)$ & $39.094(8)$ \\
\hline & Nanzuo & 1.3 & NZB33 & Tuff & 18.657 & 15.633 & 38.4 .30 \\
\hline & & 14 & NZB 7 & Tuff & 18.626 & 15.633 & 38.624 \\
\hline & & 15 & NZB8 & Tuff & 18.927 & 15.81 .5 & 39.256 \\
\hline & & 16 & $\mathrm{NZB9}$ & Limestone & 18.928 & 15.756 & 39.337 \\
\hline & & 17 & NZB 10 & Limestone & 18.598 & 15.653 & 38.836 \\
\hline & & 18 & NPTV-B 19 & Basalt & 18.865 & 15.910 & 39.431 \\
\hline & & 19 & NPD2-B4 & Keralophyre & 18.592 & 15.714 & 38.967 \\
\hline \multirow[t]{15}{*}{ Triassic } & Caizidi & 20 & CZK68TW 1 & Rhyolite & 18.524 & 15.539 & 38.950 \\
\hline & Weixi & 21 & PQTW I & Rhyolite & 18.653 & 15.625 & 38.809 \\
\hline & Kedengjian & 22 & $k-16$ & Altered andesite & $19.268(6)$ & $15.6 .34(4)$ & $38.914(7)$ \\
\hline & & 23 & $k-18$ & Altered andesile & $18.809(5)$ & $15.888(3)$ & $38.914(6)$ \\
\hline & & 24 & $k-20$ & Altered basalt & $18.553(7)$ & $15.587(4)$ & $38.431(7)$ \\
\hline & Weixi & 25 & DXQ51 & Basalı & 18.593 & 15.696 & 38.859 \\
\hline & & 26 & DXQ52 & Basalt & 18.597 & 15.685 & 38.832 \\
\hline & West Xiaguan & 27 & DXQ9 & Limestone & 18.791 & 15.619 & 38.611 \\
\hline & & 28 & DXQ10 & Limestone & 20.127 & 15.878 & 39.232 \\
\hline & & 29 & DXQ11 & Limestone & 20.184 & 15.679 & 38.547 \\
\hline & Jinding & 30 & No. 3 & Limestone & 18.544 & 15.765 & 38.914 \\
\hline & & 31 & No. 5 & Limestone & 18.888 & 15.988 & 39.464 \\
\hline & & .32 & No. 6 & Limestone & 20.289 & 16.051 & 40.890 \\
\hline & Caizidi & 33 & J)XQ49 & Iimestone & 19.204 & 15.772 & .38 .957 \\
\hline & & 34 & $1) \times Q 50$ & Limestone & 18.573 & 15.698 & 38.730 \\
\hline \multirow[t]{6}{*}{ Jurassic } & Jinman & 35 & 97.IM2 & Silicalite & $18.524(5)$ & $15.596(2)$ & $38.578(6)$ \\
\hline & & 36 & jm- 16 & Silicalite & $18.607(5)$ & $15.599(3)$ & $38.75+(7)$ \\
\hline & & 37 & $97 \mathrm{jm} 25$ & Sandstone & $18.647(4)$ & $15.589(2)$ & $38.7 .37(5)$ \\
\hline & & 38 & $\operatorname{jim} 23$ & Sláte & $18.725(4)$ & $15.593(2)$ & $38.911(6)$ \\
\hline & West Xiaguan & 39 & $\mathrm{DXQ} 15$ & I.jmestone & 18.595 & 15.807 & 39.259 \\
\hline & Jinding & 40 & IB 308 & Sandstone & 18.592 & 15.742 & 39.306 \\
\hline \multirow[t]{10}{*}{ Cretaceous } & West Xiaguan & 41 & DXQ16 & Sandstone & 18.756 & 15.713 & 39.328 \\
\hline & West Xiaguan & 42 & DXQ18 & Sandstone & 18.645 & 15.710 & .38 .912 \\
\hline & West Xiaguan & 4.3 & DXQ2I & Sandstone & 18.560 & 1.5 .714 & 38.924 \\
\hline & Jinding & 44 & No. 1 & Sandstone & 18.517 & 15.705 & 38.889 \\
\hline & Jinding & 45 & No. 2 & Sandstone & 18.707 & 15.892 & 39.317 \\
\hline & Baiyangchang & 46 & TJY-14 & Sandstone & 18.746 & 15.779 & 39.198 \\
\hline & Xiaogela & 47 & $\mathrm{~J} 5 \mathrm{~B} 91$ & Sandstone & 18.562 & 15.676 & 38.854 \\
\hline & West Xiaguan & 48 & $\mathrm{D} \times \mathrm{QQ} 22$ & Sandstone & 18.52 .3 & 15.574 & 38.749 \\
\hline & West Xiaguan & 49 & DXQ24 & Sandstone & 18.557 & 15.694 & 38.973 \\
\hline & Baiyangchang & 50 & TIY-15 & Sandstone & 18.606 & 15.768 & 39.068 \\
\hline \multirow[t]{4}{*}{ Tertiary } & Yunlong & 51 & $\mathrm{I}) \times \mathrm{Q} 26$ & Sandstone & 18.706 & 15.736 & 38.934 \\
\hline & Yunlong & 52 & DXQ27 & Sandstone & 18.543 & 15.574 & 37.882 \\
\hline & Jinding & 53 & $\mathrm{JB} 4.39$ & Sandsione & 18.488 & 15.636 & 38.6 .32 \\
\hline & Jinding & 54 & JB.54,3-I & Sandstone & 18.549 & 15.693 & 38.809 \\
\hline
\end{tabular}

Sequence Nos. 8-12, 22-24, 35-38 samples were analyzed in this study, data for the others were published by Luo et al. (1992). All samples are whole rocks. Data in the brackets are analytical errors $(2 \sigma)$. Except for the samples of this study, no analytical error values were given for the other samples. 
sandstone, limestone, andesite, etc.), they have similar lead isotopic compositions. In Fig. 4 the data points of the samples fall within the area defined by ${ }^{206} \mathrm{~Pb} /{ }^{204} \mathrm{~Pb}=18.100-20.300,{ }^{207} \mathrm{~Pb} /$ ${ }^{204} \mathrm{~Pb}=15.200-16.050$, and ${ }^{208} \mathrm{~Pb} /{ }^{204} \mathrm{~Pb}=38.255-$ 40.890 , showing a significant difference from the isotopic composition of mantle-source lead. We consider that this range of isotopic variations can approximate the lead isotopic composition of modern upper crustal rocks in the region of western Yunnan (the dotted-line areas in Fig. 4).

\section{ISOTOPIC COMPOSITION AND ORIGIN OF LEAD IN THE JINDING DEPOSIT}

The lead isotopic composition data for the fifty-five galena, sphalerite and pyrite samples used in this study are presented in Table 3 . These samples can be divided into two groups. The first group includes seventeen samples (Nos. 1-17 in Table 3). This group of samples is predominated by galena and minor sphalerite and pyrite which serve as sandstone detritus cements, and are seperated from the sandstone-type ores in the orebodies I, II and X of the upper ore-host bed. In these ores, there is a few of the late hydrothermal replacement. All samples of this group were mainly collected from the disseminated and striped ores near the edges of the ore-bodies. Their lead isotopic ratios are: ${ }^{206} \mathrm{~Pb} /{ }^{204} \mathrm{~Pb}=18.394-18.600$, ${ }^{207} \mathrm{~Pb} /{ }^{204} \mathrm{~Pb}=15.583-15.767$, and ${ }^{208} \mathrm{~Pb} /{ }^{204} \mathrm{~Pb}=$ 38.266-39.046. The second group consists of thirty-eight samples (Nos. 18-55 in Table 3), including galena in the two types (sandstone- and limestone-type) of ores from orebodies I, II, VI, VII and X of the upper and lower ore-host beds in the Baichang, Nanchang and Xipo ore runs. The ore of this group exhibits massive ore texture. The lead isotopic ratios are: ${ }^{206} \mathrm{~Pb} /{ }^{204} \mathrm{~Pb}=18.138-$ $18.552,{ }^{207} \mathrm{~Pb} /{ }^{204} \mathrm{~Pb}=15.345-15.552$, and ${ }^{208} \mathrm{~Pb} /$ ${ }^{204} \mathrm{~Pb}=37.803-38.443$. Comparitively, lead isotopic ratios in the first group of samples are higher than those of the second group. The lead model ages of the two groups of samples calculated with the two-stage model by Stacey and Krammers (1975) show that the second group of samples are dated at 29 to $40 \mathrm{Ma}$ for 19 samples, similar to fissilon track ages (25 Ma to $35 \mathrm{Ma}$ ) by Li et al. (2000), and <15 Ma or negative ages for the other samples. The lead model ages of the first group of samples range from $98 \mathrm{Ma}$ to $400 \mathrm{Ma}$, larger than those of the ore-hosted strata. The $\mu$ values calculated with the two-stage model are larger than 9.74 for the first group of samples and lower than 9.4 for the second group of samples. Differences in lead isotopic composition for the two groups of samples probably indicate the different sources of lead in the deposit.

\section{Relationship between ore lead and upper mantle lead}

It was previously considered that lead in the Jinding deposit had stemmed from the upper mantle mainly on the basis of its homogeneous lead isotopic composition and fairly primitive isotopic ratios (Yin et al., 1990; Luo et al., 1992; Tu et al., 2000). We noticed that these authors over emphasized those samples with low lead isotopic ratios in their studies. Really, the samples of the second group described above have relatively low lead isotopic ratios and some data points fall directly within the area of mantle lead in the region of western Yunnan as in Fig. 5. However, the data points of most of the ore samples fall in the lower part of the mantle lead area. If it is assumed that the mantle lead area defined by the data from western Yunnan is reliable, there would be at least two inconsistencies with the ore lead data. The first one is: Why is the trend of ore lead inconsistent with the area of mantle lead? The second is: Where did the lead in the samples falling below the mantle lead area stem from? Following this, it may be concluded from Fig. 5 that the lead in the first group of samples did not originate directly from the mantle.

\section{Relationship between ore lead and upper crustal lead}

The isotopic comparisons of ore lead with sedimentary rock lead in the Lanping Basin show that the data points of the first group of 17 samples (solid circles in Fig. 5) fall within and/or near the 
Table 3. The Pb isotopic composition of the Jinding Pn-Zn deposit

\begin{tabular}{|c|c|c|c|c|c|c|}
\hline $\begin{array}{l}\text { Seq. } \\
\text { No. }\end{array}$ & $\begin{array}{c}\text { Sample } \\
\text { No. }\end{array}$ & Mineral & Occurrence & $\begin{array}{c}{ }^{20 r i} \mathrm{~Pb} /{ }^{2+14} \mathrm{Ph} \\
(2 \sigma)\end{array}$ & $\begin{array}{c}{ }^{2117} \mathrm{~Pb} /{ }^{2 n 1} \mathrm{~Pb} \\
(2 \sigma)\end{array}$ & $\begin{array}{c}=1 \times \mathrm{Pb} /{ }^{2+\mathrm{Ph}} \mathrm{Ph} \\
(2 \sigma)\end{array}$ \\
\hline 1 & $82 \mathrm{j}-2$ & Galena & Sandstone-type ore cement from the upper ore-host bed & $18.400(4)$ & $15.612(2)$ & $38.463(5)$ \\
\hline 2 & $82 j-5$ & Galena & Sandstone-type ore cement from the upper ore-host bed & $18.441(4)$ & $15.632(3)$ & $38.660(6)$ \\
\hline 3 & $82 \mathrm{j}-11$ & Galena & Sandstone-type ore cement from the upper ore-host hed & $18.420(2)$ & $15.626(2)$ & $38.536(5)$ \\
\hline 4 & $82 i-27$ & Galena & Sandstone-type ore cement from the upper ore-host bed & $18.506(3)$ & $15.640(2)$ & $38.557(4)$ \\
\hline 5 & [BTW 1 & Galena & Orebody $I_{l}$ in the upper ore-host bed & 18.444 & 15.625 & 38.584 \\
\hline 6 & BTW2 & Galena & Orebody I in the upper ore-loost bed & 18.394 & 15.583 & 38.470 \\
\hline 7 & BTW4 & Galena & Orebody $I$ in the upper ore-host hed & 18.405 & 15.593 & 38.462 \\
\hline 8 & No4 & Galena & Orebody I in the upper ore-host bed & 18.534 & 15.754 & 39.000 \\
\hline 9 & BTWI & Sphalerite & Orebody $I_{1}$ in the upper ore-host bed & 18.566 & 15.627 & 38.675 \\
\hline 10 & BTW2 & Sphalcrite & Orebody $l$ in the upper ore-host bed & 18.543 & 15.767 & 39.046 \\
\hline 11 & BTW3 & Sphalerite & Orebody $I_{1}$ in the upper ore-host bed & 18.484 & 15.628 & .38 .598 \\
\hline 12 & BTW3 & Pyrite & Orebody I in the upper ore-host bed & 18.41 .3 & 15.597 & 38.48 .3 \\
\hline 1.3 & $82 \mathrm{j}-31$ & Galena & Coexisting with framboid pyrite from the striped ore of orebody II & $18.588(3)$ & $15.617(2)$ & $38.321(5)$ \\
\hline 14 & $82 \mathrm{j}-33$ & Galena & Coexisting with framboid pyrite from the striped ore of orebody il & $18.600(3)$ & $15.622(3)$ & $38.359(4)$ \\
\hline 15 & $82 \mathrm{j}-35$ & Galena & Disseminated ore from orebody Il of the lower ore-host bed & $18.493(4)$ & $15.619(3)$ & $38.488(5)$ \\
\hline 16 & BTW7 & Galena & Orebody XII in the lower ore-host bed & 18.443 & 15.628 & 38.516 \\
\hline 17 & Ding-3 & Galena & Lower ore-host bed & 18.523 & 15.6 .34 & 38.481 \\
\hline 18 & $82 \mathrm{j}-7$ & Galena & Coarse-grained. sandstone-type ore from the upper ore-hosted bed & $18.285(3)$ & $15.491(3)$ & $38.300(4)$ \\
\hline 19 & $82 \mathrm{j}-9$ & Galena & Coarse-grained, sandstone-type ore from the upper ore-hosted bed & $18.303(2)$ & $15.501(2)$ & $38.290(3)$ \\
\hline 20 & Yn10-1 & Galena & Orebody $l_{1}$ in the upper ore-host bed & 18.172 & 15.345 & 37.803 \\
\hline 21 & Yn10-2 & Galena & Orebody $I_{1}$ in the upper ore-host bed & 18.173 & 15.345 & 37.803 \\
\hline 22 & Yn13-1 & Galena & Orebody $I_{1}$ in the upper ore-host bed & 18.312 & 15.474 & 38.136 \\
\hline 23 & TY37 & Gatena & Orebody $I_{1}$ in the upper ore-host bed & 18.283 & 15.463 & 38.297 \\
\hline 24 & TY38 & Galena & Orebody $I_{1}$ in the upper ore-host bed & 18.222 & 15.423 & 38.093 \\
\hline 25 & TY39 & Galena & Orebody $I_{l}$ in the upper ore-host bed & 18.207 & 15.377 & 38.007 \\
\hline 26 & TY4I & Galena & Orebody $l_{1}$ in the upper ore-host bed & 18.138 & 15.352 & .37 .921 \\
\hline 27 & TY 42 & Galena & Orebody $I_{1}$ in the upper ore-host bed & 18.169 & 15.362 & 38.042 \\
\hline 28 & Yn4l & Galena & Orebody $l_{1}$ in the upper ore-host bed & 18.290 & 15.450 & 37.993 \\
\hline 29 & Yn4l-1 & Galena & Orebody $I_{1}$ in the upper ore-host bed & 18.402 & 15.549 & 38.357 \\
\hline 30 & Yn42-2 & Galena & Orebody $I_{1}$ in the upper ore-host bed & 18.346 & 15.527 & 38.286 \\
\hline 31 & Yn45 & Galena & Orebody $I_{1}$ in the upper ore-host bed & 18.351 & 15.517 & .38 .168 \\
\hline 32 & Yn46-2 & Gatena & Orebody $I_{t}$ in the upper ore-host bed & 18.31 .3 & 15.485 & 38.158 \\
\hline 33 & Yn.59 & Galena & Orebody $I_{1}$ in the upper ore-host bed & 18.188 & 15.391 & 37.889 \\
\hline 34 & Yn61 & Gallena & Orebody $I_{1}$ in the upper ore-hosi bed & 18.325 & 1.5 .495 & 38.169 \\
\hline 35 & BTW8 & Galena & Orebody $l_{1}$ in the upper ore-host bed & 18.552 & 15.552 & 38.3 .34 \\
\hline 36 & Ding- 1 & Gálena & Orehody $I_{1}$ in the upper ore-host hed & 18.195 & 15.396 & 38.11 .3 \\
\hline 37 & TY40 & Galena & Orebody $\mathrm{II}_{z}$ in the lower ore-host hed & 18.212 & 15.399 & 38.046 \\
\hline 38 & TY46 & Galena & Orebody $\mathrm{II}_{z}$ in the lower ore-lost bed & 18.220 & 15.407 & 38.155 \\
\hline 39 & $Y_{n} 55$ & Galena & Orebody $\mathrm{Il}_{2}$ in the lower ore-host hed & 18.346 & 15.513 & 38.204 \\
\hline 40 & $Y n 87$ & Galena & Orebody $\mathrm{II}_{2}$ in the lower ore-host bed & 18.333 & 15.488 & 38.146 \\
\hline 41 & Yn16-1 & Galena & Orebody $X_{1}$ in the lower ore-host bed & 18.293 & 15.499 & 38.215 \\
\hline 42 & Yn25 & Galena & Orebody $X_{1}$ in the lower ore-host bed & 18.238 & 15.404 & 37.900 \\
\hline 43 & $\mathrm{Yn} 30$ & Galena & Orebody $X_{1}$ in the lower ore-host bed & 18.322 & 15.497 & 38.178 \\
\hline 44 & Yn.31-1 & Galena & Orebody $X_{1}$ in the lower ore-host bed & 18.282 & 15.452 & 38.041 \\
\hline 45 & $Y n 31$ & Galena & Orebody $X_{1}$ in the lower ore-host bed & 18.347 & 15.521 & 38.281 \\
\hline 46 & Ty 45 & Galena & Orebody $X_{1}$ in the lower ore-host bed & 18.286 & 15.453 & 38.44 .3 \\
\hline 47 & $\mathrm{Yn} 23$ & Galena & Orebody $\mathrm{X}_{2}$ in the lower ore-bost hed & 18.267 & 15.4 .37 & 38.033 \\
\hline 48 & YnI6 & Galena & Orebody VI, in the lower ore-host bed & 18.267 & 15.466 & 38.118 \\
\hline 49 & Yn16-2 & Galena & Orebody $\mathrm{Vl}$, in the lower ore-host bed & 18.213 & 15.374 & 37.928 \\
\hline 50 & $82 j-18$ & Galcua & The massive ore from orebody vil of the lower ore-hosled hed & $18.232(1)$ & $15.476(1)$ & $38.17+(4)$ \\
\hline 51 & $82 \mathrm{j}-19$ & Galena & The massive ore from orebody VIl of the lower ore-hosted hed & $18.28 .3(3)$ & $15.493(2)$ & $38.295(5)$ \\
\hline 52 & $82 . j-26$ & Galena & The massive ore from orehody VII of the lower ore-hosted bed & $18.321(2)$ & $15.450(1)$ & $38.235(4)$ \\
\hline 53 & BTW5 & Galena & Orebody VII, in the lower ore-host bed & 18.374 & 15.504 & 38.243 \\
\hline 54 & TY43 & Galena & Orebody VII, in the lower ore-host bed & 18.247 & 15.410 & 38.226 \\
\hline
\end{tabular}

Samples 1 to 4, 13 to 15,18 to 19 and 50 to 52 by this paper, the other samples were published by Luo et al. (1992) and detailed occurrence information is not presented. Data in the brackets are analytical errors $(2 \sigma)$. Except for the samples of this study, no analytical error values were given for the other samples. 

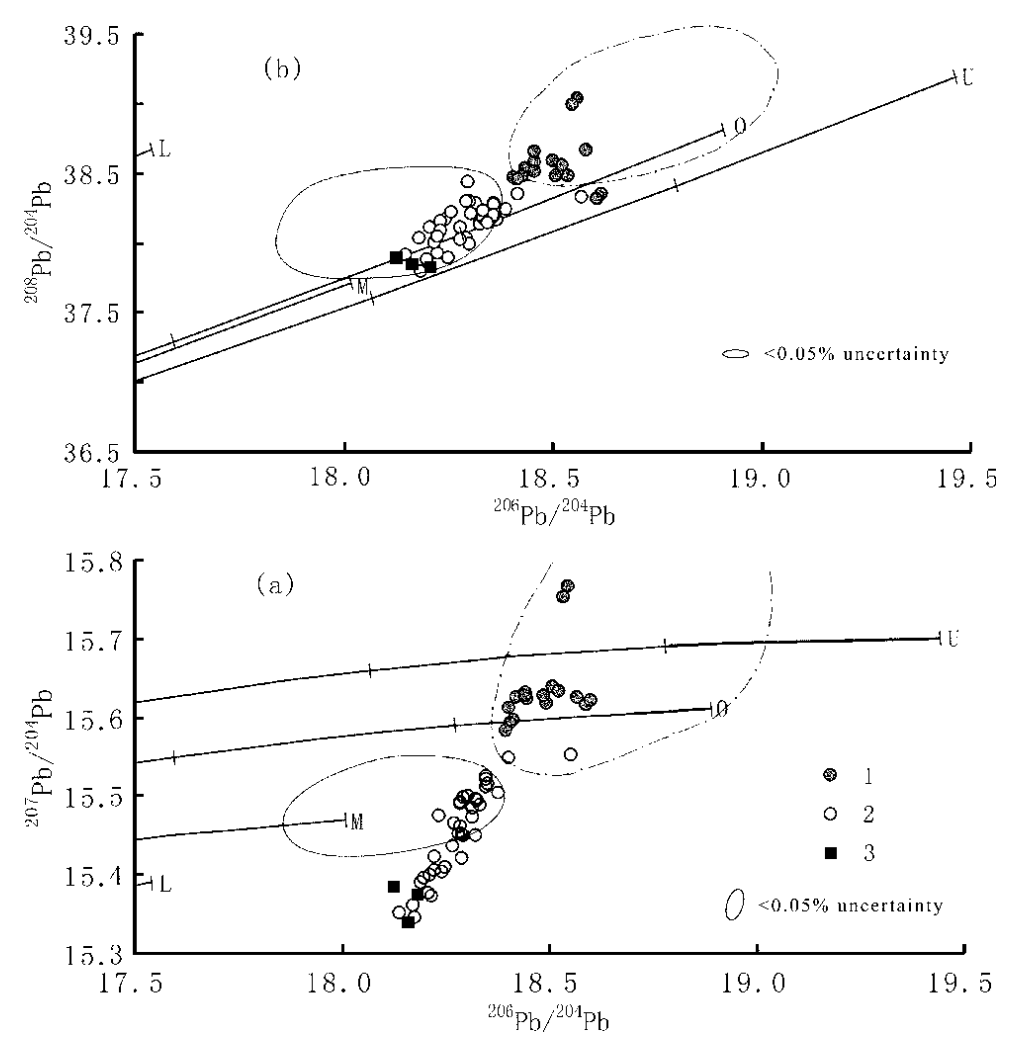

Fig. 5. Comparison of the Pb isotopic composition of the Jinding deposit with that of the mantle lead and upper crust lead in western Yunnan. Zartman's lead evolution model: M. Upper mantle lead; O. Orogenic belt lead; U. Upper crust lead; L. Lower crust lead. 1. Samples from disseminated and fine-grained ores; 2 . Samples from massive ore in the center of orebody; 3. Lower crustal lead from the minerals in granulite and eclogite xenoliths. The solid-line area: upper mantle lead in the region of western Yunnan; the dotted-line area: upper crust lead in the Laping Basin.

area of sedimentary rock lead, while those of the second group with a few exceptions fall below the area of sedimentary rock lead.

Li et al. (1993) considered that the Jinding deposit is a terrestrial exhalative-hydrothermal sedimentary deposit (terrestrial SEDEX deposit). We noticed that near the edges of the ore-bodies, especially in the upper ore-hosted bed and the western area of the ore-field, there exist bedded, laminated and disseminated ores, and spheroidal, spherulitic and framboidal pyrite. At the center of orebodies, especially in the lower ore-hosted bed, metasomatic mineralization is common. These characteristics indicate that the Jinding deposit is of exhalative-hydrothermal mineralization origin. The lead isotope data of the first group of sam- ples represent this stage of mineralization. Metasomatic mineralization postdated the sedimentary mineralization, which probably has the lead isotopic characteristics of the second group of samples.

Leaching seems to be the main mechanism by which lead in the regional upper crustal strata found its way into hydrothermal solutions and were incorporated in ore of the first-group samples. The results of leaching experiments by Lin and Guo (1985) and Andrew et al. (1990) demonstrated that in the process of leaching of the rock lead the radiogenic lead would preferentially enter the solution, resulting in higher lead isotopic ratios in the leaching solution than those in the whole-rock samples. It can therefore be deduced 


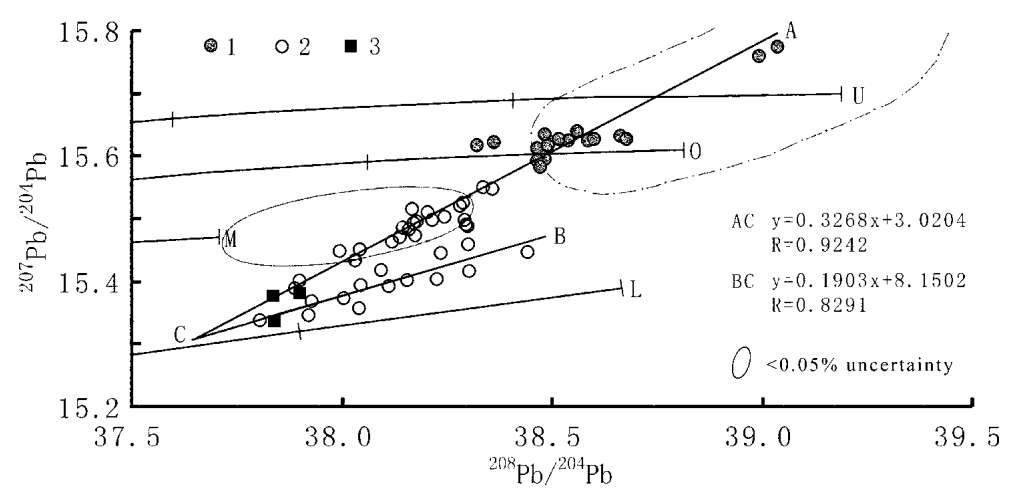

Fig. 6. ${ }^{208} \mathrm{~Pb} /{ }^{204} \mathrm{~Pb}-{ }^{207} \mathrm{~Pb} /{ }^{204} \mathrm{~Pb}$ diagram of the Jinding Pb-Zn deposit. Zartman's lead evolution model: M. Upper mantle lead; O. Orogenic belt lead; U. Upper crust lead; L. Lower crust lead. 1. Samples from disseminated and fine-grained ore; 2. Samples from massive ore in the center of orebody; 3. Lower crustal lead from the minerals in granulite and eclogite xenoliths. The solid-line area: upper mantle lead in the region of western Yunnan; the dotted-line area: upper crust lead in the Laping Basin.

that lead isotopic ratios in minerals formed from hydrothermal solutions which have assimilated lead by rock leaching should be higher, or at least should not be lower, than those in the original leached rocks. It thus can be claimed with confidence that lead in the second group of samples did not stem mainly from the upper crustal strata. By analogue, if the lead in the first group of samples was derived completely from leaching of these strata, their lead isotopic ratios should be much higher. Clearly, the lead in this deposit is not of a single source origin.

\section{A possible source of ore lead: a possible model}

The source of lead: the mixing model of upper and lower crust lead As can be seen in Fig. 5, the data points of all the ore samples are arranged linearly. Especially in the ${ }^{206} \mathrm{~Pb} /{ }^{204} \mathrm{~Pb}-{ }^{207} \mathrm{~Pb} /{ }^{204} \mathrm{~Pb}$ diagram, the linearity is more conspicuous, but of no isochronity. Based on the relationship between the ore lead and the upper crustal strata, we may consider that lead in the first group of samples, which was formed in the process of terrestrial exhalative-sedimentary mineralization, is mainly derived from upper crustal rocks in the region.

In Fig. 5a, lead in those isotopically lowest samples may have been contaminated by regionally available upper crustal lead and their isotopic signature can be approximately regarded as the lead isotopic composition of the source region for the isotopically primitive components of the second group of samples. As viewed from the data available, neither the magmatic and Precambrian metamorphic rocks and the Phanorozoic sedimentary strata (from Cambrian to Tertiary), exposed in the region of western Yunnan, nor the matle rocks in the region possess such kind of lead isotopic composition. We guess such lead is possiblly derived from the lower crust.

There is no exposure of lower crustal rocks in the wesrtern Yunnan. Fortunately, we discovered granulite and eclogite xenoliths in the aegirine syenite porphyry at Liuhe. These xenoliths may be derived from the lower crust of the region. The lead isotopic ratios in two garnet and one hornblende minerals range from 18.135 to 18.187 for ${ }^{206} \mathrm{~Pb} /{ }^{204} \mathrm{~Pb}, 15.335$ to 15.388 for ${ }^{207} \mathrm{~Pb} /{ }^{204} \mathrm{~Pb}$ and 37.836 to 37.899 for ${ }^{208} \mathrm{~Pb} /{ }^{204} \mathrm{~Pb}$, respectively. These data are the same as those of the isotopically lowest lead samples of ore (see Fig. 5).

Zhang (1992) considered that the evolution line of the lower crust lead in ${ }^{206} \mathrm{~Pb} /{ }^{204} \mathrm{~Pb}-{ }^{208} \mathrm{~Pb} /{ }^{204} \mathrm{~Pb}$ diagram by Zartman and Doe (1981) is not suitable for the situation of the Chinese continent. Really, even if the typical rocks of the lower crust in China are taken into consideration, the lead isotopic plots are far away from the lower crustal lead line. Therefore, we present the ${ }^{208} \mathrm{~Pb} /{ }^{204} \mathrm{~Pb}-{ }^{207} \mathrm{~Pb} /$ 
${ }^{204} \mathrm{~Pb}$ diagram (Fig. 6) to make a further discussion. As can be seen in Fig. 6, sample data follow two patterns of distribution. Samples of the first group and some samples of the second group are distributed along the straight line AC, with $r=$ 0.9458. The other samples of the second group are distributed along the straight line $\mathrm{BC}$ and developed near the evolution line of the lower crust lead, with $r=0.8233$. The data points of xenoliths are also plotted into the lowest part of lines AC and BC. Thus it can be seen the conclusion that lead in the second group of samples is primarily derived from the lower crust of western Yunnan is believable.

In Figs. 5 and 6, the linear distributions of sample points may be the result of mixing of lead of two sources. Because lead of the lower crustal source is involved in mineralization on the basis of hydrothermal sedimentary ore-deposition, and the mixing of lead of two sources is inevitable. Mixing in different proportions resulted in such a lead isotopic compositional pattern in the deposit.

Other lines of geochemical evidence contradicting a predominant mantle lead involvement during the ore-forming process No exposure of mantle rocks is known from the Jinding mining district and this is another piece of geological evidence to show that ore lead was not derived from the upper mantle. Various pieces of isotopic evidence are also in favor of a non-mantle origin for the Jinding deposit. For instance, no mantle-source helium has been detected in the deposit (Hu et al., 1998). Moreover, the $\delta^{34} \mathrm{~S}$ values of framboidal and fine-grained pyrite, sphalerite and galena at the edges of orebodies range from $-12 \%$ o to $-30 \%$, those of sulfide from massive ores range from $-2 \%$ o to $-24 \%$, those of celestite vary between $+11.2 \%$ and $+18.8 \%$ (Zhang, 1991), and the $\delta^{13} \mathrm{C}$ values of calcite are within the range of $-6 \%$ o to $-25 \%$ o (Luo et al., 1992). All these data display the isotopic characteristics of crust-derived components.

$\mathrm{Sr}\left({ }^{87} \mathrm{Sr} /{ }^{86} \mathrm{Sr}\right)$ isotopic ratios of celestite and gypsum in the ore are 0.71039-0.71185 (Luo et al., 1992). Recently we analyzed the Sr isotopic composition of sphalerite from orebody $\mathrm{I}_{1}$ of the
Baichang ore run. The results show ${ }^{87} \mathrm{Sr} /{ }^{86} \mathrm{Sr}$ ratios in disseminated sphalerite from the edge of the orebody are from 0.71463 to 0.72358 and those of massive sphalerite from the center of the orebody are from 0.70982 to 0.71271 . Apparently, the two types of ore have different $\mathrm{Sr}$ isotopic compositions.

To make a comparison with ore, some of $\mathrm{Sr}$ isotopic data for different geological units in western Yunnan are collected. ${ }^{87} \mathrm{Sr} /{ }^{86} \mathrm{Sr}$ ratios in gabbro and basalt range from 0.7036 to 0.7083 , those of alkaline igneous rocks range from 0.7045 to 0.7080, those of the Mesozoic S-type granite and rhyolite are from 0.7090 to 0.7139 , those of the Early and Middle Proterozoic migmatite, gneiss and schist are from 0.7159 to 0.7249 , and those of the sedimentary rocks (mainly limestone and shale) from Permian to Triassic range from 0.7191 to 0.7335 (Zhou and Liu, 1988; Lu et al., 1993; Zhong et al., 1998). We have obtained the Sr isotopic compositions of the granulite and eclogite xenoliths from the aegirine syenite porphyry, and their ${ }^{87} \mathrm{Sr} /{ }^{86} \mathrm{Sr}$ ratios are from 0.7098 to 0.7116 (three samples). These data indicate that the different geological units in western Yunnan are different from $\mathrm{Sr}$ isotopic composition.

According to the $\mathrm{Sr}$ isotope data above, it is found that in the Jinding deposit, the ${ }^{87} \mathrm{Sr} /{ }^{86} \mathrm{Sr}$ ratios of terrestrial exhalative-sedimentary sphalerite from the edge of the orebody are similar to those of the Early and Middle Proterozoic migmatite, gneiss and schist, and those of the sedimentary rocks from Permian to Triassic. The ${ }^{87} \mathrm{Sr} /$ ${ }^{86} \mathrm{Sr}$ ratios of massive sphalerite from the center of the orebody are larger than those of gabbro, basalt and ankline igneous rocks, but similar to those of xenoliths, S-type granite and rhyolite. Such similarities suggest that strontium at the early ore-forming stage (terrestrial exhalative-sedimentary mineralization stage) was probably derived from the upper crustal rocks and that at the late stage (hydrothermal metasomatic mineralization stage) from the lower crustal rocks. This conclusion is the same as what is drawn on the basis of lead isotope data. 


\section{CONClusions}

(1) The Jinding Pb-Zn deposit occurs in the Lower Tertiary red sedimentary formation in the middle part of the Lanping Basin in western Yunnan. The involvement of mantle-source lead in metallogenesis is a hypothesis that has occupied an important position for long. Nevertheless, no exposure of mantle-source magmatic rocks in the vast mining area has launched a great challenge to this hypothesis.

(2) In the region of western Yunnan the isotopic ratios of upper mantle-source lead since Meso- and Cenozoic times are approximated to: ${ }^{206} \mathrm{~Pb} /{ }^{204} \mathrm{~Pb}=17.850-18.350,{ }^{207} \mathrm{~Pb} /{ }^{204} \mathrm{~Pb}=$ 15.430-15.540, and ${ }^{208} \mathrm{~Pb} /{ }^{204} \mathrm{~Pb}=37.800-38.410$; lead isotopic ratios of the upper crust sedimentary rocks in the basin are: ${ }^{206} \mathrm{~Pb} /{ }^{204} \mathrm{~Pb}=18.420$ $19.200,{ }^{207} \mathrm{~Pb} /{ }^{204} \mathrm{~Pb}=15.500-16.010$, and ${ }^{208} \mathrm{~Pb} /$ ${ }^{204} \mathrm{~Pb}=38.450-39.500$; lead isotopic ratios of several garnet and hornblende samples from lower crust-derived granulite and eclogite xenoliths range from 18.135 to 18.187 for ${ }^{206} \mathrm{~Pb} /{ }^{204} \mathrm{~Pb}$, 15.335 to 15.388 for ${ }^{207} \mathrm{~Pb} /{ }^{204} \mathrm{~Pb}$ and 37.836 to 37.899 for ${ }^{208} \mathrm{~Pb} /{ }^{204} \mathrm{~Pb}$.

(3) There are two different types of the ore lead isotopes in the Jingding deposit. The lead isotopic ratios of the massive ore are from 18.138 to 18.552 for ${ }^{206} \mathrm{~Pb} /{ }^{204} \mathrm{~Pb}, 15.345$ to 15.552 for ${ }^{207} \mathrm{~Pb} /{ }^{204} \mathrm{~Pb}$, and 37.803 to 38.443 for ${ }^{208} \mathrm{~Pb} /{ }^{204} \mathrm{~Pb}$, and the lead isotopic ratios of the striped ore are from 18.394 to 18.600 for ${ }^{206} \mathrm{~Pb} /{ }^{204} \mathrm{~Pb}, 15.583$ to 15.767 for ${ }^{207} \mathrm{~Pb} /{ }^{204} \mathrm{~Pb}$, and 38.266 to 39.046 for ${ }^{208} \mathrm{~Pb} /{ }^{204} \mathrm{~Pb}$. Based on a comparison with the lead isotopic compositions, lead in the deposit was not derived from the upper mantle. Instead, it may stem from the two geological units: one is the upper crust and the other is probably the lower crust. The upper crustal source lead is incorporated into ore during the early sedimentary mineralization stage, and the lower crustal source lead is incorporated into ore during the late hydrothermal metasomatic mineralization stage.

Acknowledgments-This research is supported by the State Major Basic Research Program (G1999043208) of People's Republic of China and Major Research
Project (KZ952-S1-407) of CAS. The authors wish to thank Mr. Qiao Guangsheng with the Isotope Lab. of the Institute of Geology, CAS, Ms. Peng Jianhua with the State Key Lab. of Environmental Geochemistry, CAS, and Mr. Zhu Jiaping and Mr. Li Huaqin with the Isotope Analysis Center of Yichang Institute of Geology and Mineral Resources, Chinese Academy of Geological Sciences for their help with isotopic analysis.

\section{REFERENCES}

Andrew, W. M., Pablo, M., Anne, P. L. and Ulrich, P. (1990) Lead isotope provinces of the Central Andes inferred from ores and crustal rocks. Econ. Geol. 85, 1857-1880.

Bai, J., Wang, C. and Na, R. (1985) Geology of the Jinding $\mathrm{Pb}-\mathrm{Zn}$ deposit in Yunnan. Mineral Deposits 4, 1-10 (in Chinese with English abstract).

Bian, Q. (1998) The crust/mantle texture and structure of the Earth and their relation with the Laowangzhai superlarge gold deposit. Science in China (Series D) 28, 303-309 (in Chinese with English abstract).

Chen, G., Yin, H., Chu, Y. and Liu, D. (1996) Organic matter characteristics of Tertiary deposits in the Shimao Basin, Lanping and their geological implications. Mineral Deposits 15, 374-380 (in Chinese with English abstract).

Deng, W., Huang, X. and Zhong, D. (1998) Petrology and origin of the Cenoozoic alkali-rich porphyries in western Yunnan. Scientia Geologica Sinica 33, 412-425 (in Chinese with English abstract).

Hu, R., Turner, G., Burnard, P. G., Zhong, H., Ye, Z. and $\mathrm{Bi}, \mathrm{X}$. (1998) Helium and argon isotopic geochemistry of Jinding superlarge $\mathrm{Pb}-\mathrm{Zn}$ deposit. Science in China (Series D) 41, 442-448.

Li, C., Wang, J. and Xiao, R. (1993) Continental hydrothermal sedimentary minerogenesis in western Yunnan. Geology of Uranium Deposits 9, 14-21 (in Chinese with English abstract).

Li, G. (1994) Studies on some overthrust nappe structures in the Lanping Basin. Yunnan Geology 13, 203212 (in Chinese with English abstract).

Li, X., Tan, K., Gong, G. and Gong, W. (2000) Prelimary studies of tectonothermal evolution and metallogenic processes in Lanping basin with fission track analysis. J. Mineral and Petrology 20, 40-42 (in Chinese with English abstract).

Lin, E. and Guo, Y. (1985) Pb isotopic study of the gold deposit-concentrated area. Journal of Changchun College of Geology 4, 1-10 (in Chinese with English abstract).

Liu, X., Zhan, X., Gao, Z., Liu, J., Li, C. and Su, W. (1999) Deep xenoliths in alkalic porphyry, Liuhe, Yunnan, and implications to petrogenesis of alkalic 
porphyry and associated mineralizations. Science in China (Series D) 42, 623-635.

Lu, B., Duan, J. and Pan, C. (1993) Granitoids in the Sanjiang Region and Their Metallogenetic Speciality. Geological Publishing House, Beijing, 262 pp. (in Chinese).

Luo, J., Yang, Y. and Zhao, Z. (1992) The Evolution of the Tethys and Metallogenesis of the Main ore Deposits in Western Yunnan. Geological Publishing House, Beijing, 214 pp. (in Chinese).

Pan, J., Zhang, Q., Ma, D. and Li, C. (2000) Stable isotope geochemical characteristics of the Yangla copper deposit in western Yunnan Province. SCTA Mineralogica Sinica 20, 385-389 (in Chinese with English abstract).

Pan, J., Zhang, Q., Ma, D. and Li, C. (2001) Cherts from the Yangla copper deposit, western Yunnan Province: geochemical characteristics and relationship with massive sulfide mineralization. Science in China (Series D) 44, 237-244.

Robin, M. B., Joaquin, R., Spencer, R. T., Richard, M. T. and Joseph, L. W. (1999) Lead isotope compositions of Late Cretaceous and Early Tertriary igneous rocks and sulfide minerals in Arizona: implications for the sources of plutons and metals in porphyry copper deposits. Econ.Geol. 94, 211-244.

Stacey, J. S. and Krammers, J. D. (1975) Approximation of terrestrial lead isotope evolution by a twostage model. Earth Planet. Sci. Lett. 26, 207-221.

Tu, G. (1989) On the alkali-rich intrusive rocks. Mineral Resources and Geology 13, 1-4 (in Chinese with English abstract).
Tu, G. et al. (1984) Geochemistry of Strata-bound Ore Deposits in China (Volume 1). Science Press, Beijing, 354 pp. (in Chinese).

Tu, G. et al. (2000) The Super-Large Deposits in China (I). Science House, Beijing, 584 pp. (in Chinese).

Xu, P., Jia, X., Qian, Q., Han, S. and Zhang, Q. (1999)

Geochemical characteristics of mafic-ultramafic sill swarm in Jinping County, Yunnan. Scientia Geologica Sinica 34, 233-241 (in Chinese with English abstract).

Yin, H., Fan, W. and Lin, G. (1990) Deep processes and mantal-crust compound mineralization in the evolution of the Lanpin-Simao Mesozoic-Cenozoic Diwa basin in Western Yunnan, China. Geotectonica et Metallogenia 14, 113-124 (in Chinese with English abstract).

Zartman, R. E. and Doe, B. R. (1981) Plumbotectonics-The model. Tectonophysics 75, 135-162.

Zhang, L. (1992) Present status and aspects of lead isotope geology. Geology and Prospecting 28, 21-29 (in Chinese with English abstract).

Zhang, Q. (1991) A study on genesis of Jinding Pb-Zn deposit in Yunnan Province. Contributions to Geol. Mineral Resources Research 6, 47-58 (in Chinese with English abstract).

Zhong, D. et al. (1998) The Palaeo-Tethyan Orogenic Zone of the Western Sichuan and Yunnan. Science House, Beijing, 231 pp. (in Chinese).

Zhou, M. and Liu, Y. (1988) The Geological Tectonic Characteristics and Evolution in Xichang-MidYunnan Region. Chongqing Publishing House, Chongqing, 166 pp. (in Chinese). 